\title{
PENGARUH SOAL HIGHER ORDER THINKING SKILL (HOTS) TERHADAP KETERAMPILAN BERPIKIR KRITIS DAN HASIL BELAJAR SISWA PADA TEMA 8 SUB TEMA 3 DI KELAS IV SEKOLAH DASAR
}

\author{
Agustin Mutia Miftakhul Hasanah ${ }^{1}$, Satrio Wibowo ${ }^{2}$, Budhi Rahayu Sri Wulan ${ }^{3}$ \\ ${ }^{123}$ STKIP PGRI SIDOARJO \\ miftakhulhasanah994@gmail.com
}

\begin{abstract}
Abstrak
Tujuan dari penelitian ini adalah 1. Untuk mengetahui pengaruh soal HOTS terhadap keterampilan berpikir kritis siswa pada tema 8 sub tema 3 pembelajaran 1 dan pembelajaran 2 di kelas IV SD. 2. Untuk mengetahui pengaruh soal HOTS terhadap hasil belajar siswa pada tema 8 sub tema 3 pembelajaran 1 dan pembelajaran 2 di kelas IV SD. 3. Untuk mengetahui respon siswa terhadap soal HOTS pada tema 8 sub tema 3 pembelajaran 1 dan pembelajaran 2 di kelas IV SD. Jenis penelitian ini yaitu penelitian kuantitatif dengan metode eksperimen. Sampel penelitian ini adalah 11 siswa SDN Mojorangagung dan 11 siswa SDN Kebaron. Penelitian ini menggunakan metode tes tulis untuk mengetahui tingkat keterampilan berpikir kritis dan hasil belajar dan angket untuk mengetahui respon siswa. Hasil penelitian ini membuktikan bahwa terdapat pengaruh soal HOTS terhadap keterampilan berpikir kritis sebesar 55,7\% dan memperoleh nilai korelasi sebesar 0,746 menunjukkan tingkat hubungan kuat. Hasil penelitian ini juga membuktikan bahwa terdapat pengaruh soal HOTS terhadap hasil belajar siswa sebesar 49,0\% dan memperoleh nilai korelasi sebesar 0,700 menunjukkan tingkat hubungan kuat. Hasil penelitian ini juga membuktikan terdapat respon sangat baik dari siswa hal ini dapat diketahui melalui persentase yang diperoleh yakni 89,09\%.
\end{abstract}

Kata Kunci: Soal HOTS, keterampilan berpikir kritis, hasil belajar

\begin{abstract}
The aims of this study are 1. To determine the effect of HOTS questions on students' critical thinking skills on theme 8 , sub-theme 3 , learning 1 and learning 2 in fourth grade elementary school. 2. To find out the effect of HOTS questions on student learning outcomes in theme 8, sub-theme 3, learning 1 and learning 2 in grade IV SD. 3. To find out student responses to the HOTS questions on theme 8, sub-theme 3, learning 1 and learning 2 in grade IV SD. This type of research is quantitative research with experimental methods. The sample of this study were 11 students of SDN Mojorangagung and 11 students of SDN Kebaron. This study used a written test method to determine the level of critical thinking skills and learning outcomes and a questionnaire to determine student responses. The results of this study prove that there is an effect of HOTS questions on critical thinking skills of $55.7 \%$ and obtaining a correlation value of 0.746 indicates a strong relationship level. The results of this study also prove that there is an effect of HOTS questions on student learning outcomes by $49.0 \%$ and obtaining a correlation value of 0.700 indicates a strong relationship level. The results of this study also prove that there is a very good response from students, this can be seen through the percentage obtained, namely $89.09 \%$.
\end{abstract}

Keywords: HOTS questions, critical thinking skills, learning outcomes 


\section{A. PENDAHULUAN}

Seperti yang kita ketahui, pendidikan formal di Indonesia saat ini menggunakan kurikulum 2013 atau sering disebut dengan K13. Di jenjang SD penggunaan K13 sudah diterapkan mulai dari kelas I sampai kelas VI. Menurut Andjariani (2019:32) pada kurikulum 2013 siswa dituntut untuk memiliki keterampilan menalar, mengolah, dan menyaji dengan kreatif, kritis, mandiri, kolaboratif dan komunikatif. Kemampuan berpikir tersebut masuk kedalam kategori keterampilan berpikir tingkat tinggi (Higher Order Thinking Skill). Menurut Ansari (2020:1) keterampilan berpikir tingkat tinggi merupakan suatu kegiatan berpikir pada ranah kognitif tingkat tinggi dari Taksonomi Bloom yang meliputi analisis (C4), evaluasi (C5), dan kreasi (C6). Keterampilan berpikir tingkat tinggi atau Higher Order Thinking Skill (HOTS) merupakan keterampilan yang mencakup keterampilan berpikir kritis, berpikir kreatif, dan memecahkan masalah yang melibatkan kegiatan berpikir pada tingkat kognitif antara lain analisis, evaluasi, dan kreasi / mencipta. Maka dari itu, diperlukan soal yang berbasis HOTS digunakan untuk melatih keterampilan siswa dalam memecahkan masalah, berpikir kreatif, dan berpikir kritis. Menurut Lismaya (2019:8) berpikir kritis yaitu proses intelektual yang bertujuan untuk meyakini suatu hal supaya dapat melakukan tindakan dengan cara mengevaluasi informasi yang diperoleh melalui observasi, pengalaman, pemikiran, atau komunikasi.

Berdasarkan pengalaman peneliti saat melaksanakan magang 3 (PPL) pada bulan oktober sampai november 2020 di SDN Kepunten dan hasil wawancara peneliti dengan guru wali kelas. Guru biasanya memberikan soal yang bersifat campuran yakni berbasis Lower Order Thinking Skill (LOTS) dan berbasis Higher Order Thinking Skill (HOTS). Siswa tidak sepenuhnya diberikan soal HOTS, sehingga keterampilan berpikir kritis siswa belum sepenuhnya dilatih. Maka dari itu, peneliti ingin mencoba memberikan soal-soal yang seluruhnya berbasis HOTS kepada siswa kelas IV, dengan harapan pemberian soal berbasis HOTS dapat melatih serta meningkatkan keterampilan berpikir kritis dan hasil belajar siswa. Dalam hal ini, tema yang dipilih yaitu tema 8 (Daerah tempat tinggalku) sub tema 3 (Bangga terhadap daerah tempat tinggalku) pembelajaran 1 dan pembelajaran 2 .

Terdapat beberapa penelitian terdahulu yang berkaitan dengan yang akan diteliti oleh peneliti. Penelitian dari Intan tahun 2020 dengan judul "Kemampuan siswa dalam mengerjakan soal HOTS (Higher Order Thinking Skills) pada pembelajaran matematika di kelas V sekolah dasar". Hasil dari penelitian ini menunjukkan bahwa kemampuan siswa dalam mengerjakan soal HOTS pada pembelajaran matematika masuk dalam kategori cukup baik. 
Sedangkan, penelitian dari Ula pada tahun

2019 dengan judul "Pengaruh problem based learning (PBL) dengan mind mapping terhadap keterampilan berpikir kritis". Hasil dari penelitian ini menunjukkan bahwa terdapat peningkatan keterampilan berpikir kritis siswa pada saat sesudah pembelajaran baik di kelas kontrol maupun kelas ekperimen. Sementara itu, penelitian dari Mediansyah pada tahun 2020 dengan judul "Pengaruh penerapan model pembelajaran DL (Discovery Learning) berbasis HOTS terhadap hasil belajar pada mata pelajaran IPA siswa kelas V SDN 99 kota Bengkulu". Hasil dari penelitian ini menunjukkan bahwa terdapat pengaruh yang signifikan antara model pembelajaran DL berbasis HOTS dengan hasil belajar siswa. Perbedaan penelitian ini dengan penelitian yang relevan adalah untuk mengetahui pengaruh soal Higher Order Thinking Skill (HOTS) terhadap keterampilan berpikir kritis dan hasil belajar siswa pada tema 8 sub tema 3 di kelas IV sekolah dasar.

Berikut indikator soal HOTS yang digunakan pada penelitian ini berdasrkan pendapat (Zakiah, 2019:41):
Tabel 1. Indikator Higher Order

Thinking Skill (HOTS)

\begin{tabular}{|l|l|}
\hline Indikator & \multicolumn{1}{|c|}{ Keterangan } \\
\hline $\begin{array}{l}\text { Analisis } \\
\text { (C4) }\end{array}$ & $\begin{array}{l}\text { Siswa dapat menganalisis berbagai } \\
\text { pengetahuan yang diperoleh supaya } \\
\text { dapat membedakan, mengorganisasi } \\
\text { dan menghubungkan. }\end{array}$ \\
\hline $\begin{array}{l}\text { Evaluasi } \\
\text { (C5) }\end{array}$ & $\begin{array}{l}\text { Siswa dapat membuat keputusan } \\
\text { dengan mengecek dan mengkritisi }\end{array}$ \\
\hline $\begin{array}{l}\text { Mencipta } \\
\text { / kreasi } \\
\text { (C6) }\end{array}$ & $\begin{array}{l}\text { Siswa dapat membentuk satu } \\
\text { kesatuan yang fungsional menjadi } \\
\text { struktur baru melalui proses } \\
\text { membangkitkan, merencanakan atau } \\
\text { menghasilkan. }\end{array}$ \\
\hline
\end{tabular}

Berikut indikator keterampilan berpikir kritis yang digunakan pada penelitian ini sebagai pedoman penilaian berdasarkan pendapat (Facione, 2015:9-10) :

Tabel 2. Indikator Keterampilan

Berpikir Kritis

\begin{tabular}{|l|l|}
\hline \multicolumn{1}{|c|}{ Indikator } & \multicolumn{1}{|c|}{ Keterangan } \\
\hline $\begin{array}{l}\text { Interpretation } \\
\text { (penafsiran) }\end{array}$ & $\begin{array}{l}\text { Siswa dapat menuliskan } \\
\text { jawaban sesuai dengan } \\
\text { pertanyaan dengan tepat }\end{array}$ \\
\hline $\begin{array}{l}\text { Analysis } \\
\text { (Analisis) }\end{array}$ & $\begin{array}{l}\text { Siswa dapat mengidentifikasi } \\
\text { dan menguraikan informasi } \\
\text { yang didapat secara actual } \\
\text { untuk mengungkapkap } \\
\text { keyakinan dengan tepat }\end{array}$ \\
\hline $\begin{array}{l}\text { Inference } \\
\text { (Kesimpulan) }\end{array}$ & $\begin{array}{l}\text { Siswa dapat mengidentifikasi } \\
\text { dan memperoleh unsur-unsur } \\
\text { untuk menarik kesimpulan } \\
\text { yang masuk akal }\end{array}$ \\
\hline $\begin{array}{l}\text { Evaluation } \\
\text { (Evaluasi) }\end{array}$ & $\begin{array}{l}\text { Siswa dapat menguji } \\
\text { kebenaran yang ada } \\
\text { berdasarkan persepsi, } \\
\text { pengalaman, keyakinan, atau } \\
\text { opini }\end{array}$ \\
\hline $\begin{array}{l}\text { Explanation } \\
\text { (Penjelasan) }\end{array}$ & $\begin{array}{l}\text { Siswa dapat menyatakan dan } \\
\text { membenarkan alasan dengan } \\
\text { memberikan argumen yang } \\
\text { kuat }\end{array}$ \\
\hline
\end{tabular}




\begin{tabular}{|l|l|}
\hline Self- & Siswa dapat mengoreksi hasil \\
Regulation & tes kognitif temannya dengan \\
(Regulasi & tepat \\
Diri) & \\
\hline
\end{tabular}

\section{B. METODE PENELITIAN}

Jenis penelitian yang digunakan pada penelitian ini yaitu penelitian kuantitatif dengan metode eksperimen. Menurut Sugiyono (2011:7) metode penelitian kuantitatif yaitu metode yang hasil penelitiannya berupa angka-angka dan menganalisis dengan ilmu statistik. Sedangkan metode eksperimen menurut Sugiyono (2011:72) metode penelitian digunakan untuk mencari pengaruh terhadap suatu perlakuan tertentu dalam kondisi dikendalikan.Penelitian ini menggunakan metode kuantitatif dengan pendekatan Nonequivalent Control Group Design yaitu penelitian yang terdiri dari kelompok kontrol dan kelompok eksperimen (Sugiyono, 2011:79). Penelitian ini dilakukan di SDN Mojorangagung dan SDN Kebaron tahun ajaran 2020/2021 pada semester genap. Pada penelitian ini yang menjadi populasi adalah siswa kelas IV SDN Mojorangagung Kecamatan Wonoayu yang berjumlah 22 siswa dan siswa kelas IV SDN Kebaron Kecamatan Tulangan yang berjumlah 27 siswa. Teknik pengambilan data pada sampel ini dengan cara sampling purposive yaitu 11 siswa kelas IV SDN Mojorangagung dan 11 siswa kelas IV SDN Kebaron.
Instrumen data yang digunakan pada penelitian ini yaitu lembar lembar validasi ahli, lembar observasi keterampilan berpikir kritis, lembar penilaian hasil belajar, dan lembar angket respon siswa. Validasi ahli digunakan untuk mengetahui kevalidan pada instrumen yang akan digunakan penelitian, lembar observasi keterampilan berpikir kritis digunakan untuk mengetahui bagaimana keterampilan berpikir kritis siswa berdasarkan pada pedoman penialain 6 indikator keterampilan berpikir kritis, lembar hasil belajar digunakan untuk mengetahui perolehan nilai siswa yang terdiri dari 10 soal uraian pretest dan posttest, dan lembar angket respon siswa digunakan untuk mengetahui bagaimana respon siswa terhadap soal HOTS. Sedangkan teknik analisis data yang digunakan pada penelitian ini antara lain validasi ahli, uji reliabilitas tes, hasil observasi keterampilan berpikir kritis, tes hasil belajar, hasil angket, uji regresi, uji normalitas, dan uji hipotesis.

\section{HASIL DAN PEMBAHASAN}

Hasil uji validasi soal HOTS yang terdiri dari 2 validator yakni salah satu dosen STKIP PGRI Sidoarjo sebagai ahli soal 1 dan guru kelas 4 sebagai ahli soal 2. Ahli soal 1 mendapatkan persentase 95,83\% masuk dalam kriteria sangat baik sedangkan ahli soal 2 mendapatkan persentase 79,16\% masuk dalam kriteria layak. Berdasarkan hasil uji validasi tersebut maka soal HOTS 
Pengaruh Soal Higher Order Thinking Skill (HOTS) ...

layak digunakan untuk melaksanakan

penelitian. Setelah dilakukan uji validasi selanjutnya yakni uji reliabilitas yang menggunakan bantuan program IBM SPSS 24.0, menunjukkan bahwa instrument yang digunakan penelitian reliable karena nilai alpha cronbach's sebesar 0,886 dan lebih dari 0,6.

Pengaruh soal HOTS terhadap keterampilan berpikir kritis siswa kelas IV sekolah dasar berdasarkan hasil perhitungan uji regresi linear sederhana dengan program IBM SPSS Statistic 24 mendapatkan hasil sebesar $55,7 \%$ dan sisanya 44,3\% ditentukan oleh variabel lain yang tidak digunakan pada penelitian ini. Sedangkan, nilai korelasi yang diperoleh sebesar 0,746 menunjukkan bahwa korelasi tersebut positif dan memiliki tingkat hubungan kuat. Berdasarkan perhitungan dengan SPSS didapatkan hasil nilai probabilitas signifikan $\quad 0,102>$ 0,05 maka $\mathrm{H}_{0}$ diterima. Sehingga asumsi diterima bahwa data pada kelas eksperimen dan kontrol berdistribusi normal. Berdasarkan perhitungan menggunakan program SPSS 24 thitung diketahui sebesar 5,015. Langkah selanjutnya yaitu menentukan $t_{\text {tabel }}$ dengan taraf signifikan 0,05 sebagai berikut.

$$
\begin{aligned}
& \mathrm{t}_{\text {tabel }}\left(\left(\frac{a}{2}\right)=(0,025 ; 22-2)\right. \\
& =(0,025 ; 19) \\
& =2,093 \\
& \mathrm{t}_{\text {hitung }}=5,015>\mathrm{t}_{\text {tabel }}=2,093 \text { sehingga }
\end{aligned}
$$

$\mathrm{H}_{0}$ ditolak
Nilai signifikan $=0,000<0,05$ sehingga $\mathrm{H}_{0}$ ditolak

Hasil keputusan uji hipotesis menunjukkan bahwa ada pengaruh soal HOTS terhadap keterampilan berpikir kritis siswa pada tema 8 sub tema 3 di kelas IV sekolah dasar.

Sedangkan pengaruh soal HOTS terhadap hasil belajar siswa kelas IV sekolah dasar berdasarkan hasil perhitungan uji regresi linear sederhana dengan program IBM SPSS Statistic 24 mendapatkan hasil sebesar 49,0\% dan sisanya 51,0\% ditentukan oleh variabel lain yang tidak digunakan dalam penelitian ini. Sedangkan nilai korelasi sebesar 0,700 yang menunjukkan bahwa korelasi tersebut positif dan memiliki tingkat hubungan kuat. Berdasarkan perhitungan dengan SPSS didapatkan hasil nilai probabilitas signifikan 0,063 > 0,05 maka $\mathrm{H}_{0}$ diterima. Sehingga asumsi diterima bahwa data pada kelas eksperimen dan kontrol berdistribusi normal. Langkah selanjutnya yaitu menentukan $t_{\text {tabel }}$ dengan taraf signifikan 0,05 sebagai berikut.

$$
\begin{aligned}
t_{\text {tabel }}\left(\left(\frac{a}{2}\right)\right. & =(0,025 ; 22-2) \\
& =(0,025 ; 19) \\
& =2,093 \\
t_{\text {hitung }} & =4,386>t_{\text {tabel }}=2,093
\end{aligned}
$$

sehingga $\mathrm{H}_{0}$ ditolak

$$
\text { Nilai signifikan }=0,000<0,05
$$

sehingga $\mathrm{H}_{0}$ ditolak

Hasil keputusan uji hipotesis menunjukkan bahwa ada pengaruh soal HOTS terhadap 
Pengaruh Soal Higher Order Thinking Skill (HOTS) ...

hasil belajar siswa pada tema 8 sub tema 3

di kelas IV sekolah dasar.

Respon siswa terhadap soal HOTS masuk dalam kriteria sangat baik. Hal ini berdasarkan pada total skor yang diperoleh yaitu 49 dengan persentase 89,09\%. Sehingga soal HOTS bisa digunakan untuk proses pembelajaran sehari-hari. Karena, siswa memberikan respon positif pada soal HOTS, selain itu dengan membiasakan siswa mengerjakan soal yang berbasis HOTS maka keterampilan berpikir kritis dan hasil belajar siswa akan meningkat.

\section{SIMPULAN}

Berdasarkan hasil penelitian yang telah dilaksanakan oleh peneliti pada siswa kelas IV sekolah dasar dapat disimpulkan bahwa :

1. Pengaruh soal HOTS terhadap keterampilan berpikir kritis siswa pada tema 8 sub tema 3 pembelajaran 1 dan pembelajaran 2 di kelas IV SD sebesar $55,7 \%$, artinya terdapat pengaruh yang signifikan pada soal HOTS terhadap keterampilan berpikir kritis siswa. Maka pernyataan jawaban dari hipotesis penelitian yaitu $\mathrm{H}_{0}$ ditolak dan $\mathrm{H}_{1}$ diterima

2. Pengaruh soal HOTS terhadap hasil belajar siswa pada tema 8 sub tema 3 pembelajaran 1 dan pembelajaran 2 di kelas IV SD sebesar 49,0\%, artinya terdapat pengaruh yang signifikan pada soal HOTS terhadap hasil belajar siswa.
Maka pernyataan jawaban dari hipotesis penelitian yaitu $\mathrm{H}_{0}$ ditolak dan $\mathrm{H}_{1}$ diterima

3. Respon siswa terhadap soal HOTS pada tema 8 sub tema 3 pembelajaran 1 dan pembelajaran 2 di kelas IV SD dalam kategori sangat baik. Hal ini dapat dilihat pada skor yang diperoleh 49 dengan persentase $89,09 \%$.

\section{E. DAFTAR PUSTAKA}

Andjariani, E. W. (2020). Peningkatan Aktivitas Dan Hasil Belajar Matematika Soal Cerita Bangun Datar Kelas IV SD Dengan Pembelajaran Kooperatif Model Ajataka. Jurnal Primary: (Kajian Ilmu Pendidikan Dasar dan Humaniora), 1.

Ansari, B. I., \& Abdullah, R. (2020). Higher-Order-Thinking Skill (Hots) Bagi Kaum Milenial Melalui Inovasi Pembelajaran Matematika. Malang: CV IRDH.

Facione, P. (2015). Critical Thinking: What It Is and Why It Counts.

Intan, F. M., Kuntarto, e., \& alirmansyah. (2020). Kemampuan Siswa Dalam Mengerjakan Soal HOTS (Higher Order Thinking Skills) Pada Pembelajaran Matematika Di Kelas $V$ Sekolah Dasar. Jurnal Pendidikan Indonesia.

Lismaya, L. (2019). Berpikir Kritis \& PBL (Problem Based Learning). Surabaya: Media Sahabat Cendekia.

Mediansyah. (2020). Pengaruh Penerapan Model Pembelajaran DL (Discovery Learning) Berbasis HOTS Terhadap Hasil Belajar Pada Mata Pelajaran IPA Siswa Kelas V SDN 99 Kota Bengkulu. 
Pengaruh Soal Higher Order Thinking Skill (HOTS) ...

Sugiyono. (2011). Metode Penelitian Kuantitatif Kualitatif Dan $R \& D$. Bandung: ALFABETA.

Ula, W. R. (2019). Pengaruh Problem Based Learning (PBL) dengan mind mapping terhadap keterampilan berpikir kritis.

Zakiah, L., \& Lestari, I. (2019). Berpikir kritis dalam konteks pembelajaran. Bogor: Erzatama Karya Abadi. 